\title{
Prevalence of Ticks and Tick-Borne Diseases in Indonesian Dogs
}

Upik Kesumawati Hadi ${ }^{*}$, Susi Soviana and Ignasius Resa Christanto Pratomo

Division of Parasitology and Medical Entomology, Faculty of Veterinary Medicine, Bogor Agricultural University, Jln Agatis Bogor 16880, Indonesia

*Corresponding author: Upik Kesumawati Hadi, Division of Parasitology and Medical Entomology, Faculty of Veterinary Medicine, Bogor Agricultural University, Jln Agatis Bogor 16880, Indonesia, Tel: 0251-8421784; E-mail: upikke@ipb.ac.id

Rec date: Dec 31, 2015; Acc date: Apr 16, 2016; Pub date: Apr 18, 2016

Copyright: $\odot 2016$ Hadi UK, et al. This is an open-access article distributed under the terms of the Creative Commons Attribution License, which permits unrestricted use, distribution, and reproduction in any medium, provided the original author and source are credited.

\begin{abstract}
The brown dog tick (Rhipicephalus sanguineus) is the most common ectoparasites of dog in the world. The study of ticks infestation and tick-borne diseases on the dog is necessary, because this information still limited in Indonesia. Ticks and dog blood test sampling were done at Animal Police Directorate Security Agency (Baharkam) and Atang Sendjaja Air Force (ATS). In addition, ticks and cases on ticks infestation data were obtained from 21 veterinary clinics in Bogor, Jakarta and Bandung. All ticks samples were preserved in bottles containing $70 \%$ alcohol for identification, and dog blood tests performed for Ehrlichiosis, Babesiosis and Anaplasmosis diagnosis. This research was done in March to December 2013. The results showed that all ticks samples collected from Baharkam dogs, ATS dogs and Veterinary Clinics in Bogor, Jakarta and Bandung were identified as one species, i.e., Rhipicephalus sanguineus. The prevalence of dogs infested by ticks were $67.90 \%$ in Baharkam $100 \%$ in ATS, and the prevalence in 21 Veterinary Clinic in Jakarta, Bogor, and Bandung from 2008-2013 tend to be increased every year. The tick predilections in Baharkam dogs distributed on the back regio (35.0\%), the head, ears and neck $(29.0 \%)$, the legs and the interdigital spaces $(14.5 \%)$, the abdomen $(10.9 \%)$ and the tail $(10.9 \%)$. The tick larvae were found not only in the kennel but also on the grass field of Baharkam which often use for the training of police dogs. These places can be a source of transmission of tick infestation among dogs. The purebred and male dogs in Bogor, Jakarta and Bandung were more infested than the crossbred, local and female dogs. The prevalence of Ehrlichiosis on Baharkam dog was $12 \%$, and $40 \%$ from ATS dogs. The results of blood smear examination on Baharkam dogs showed positive Babesia (8\%) and Anaplasma (16\%). There was no relationship between the degree of tick infestations to $E$. canis, Babesia and Anaplasma infections ( $p>0.05)$.
\end{abstract}

Keywords: Anaplasma; Babesia; Ehrlichia canis; Rhipicephalus sanguineus

\section{Introduction}

The brown dog tick ( $R$. sanguineus) is the most common ectoparasites of dog in the world [1] and also in Indonesia [2]. This tick feeds on a wide variety of mammals including human and birds (by attaching to the skin and sucking blood. However, dogs are its preferred host and are where it is most commonly found. The brown dog tick can cause skin irritation in dogs where large numbers are present. It can infest houses and kennels [3]. More significantly, the tick can carry and spread a range of blood-borne diseases that can affect both animals and humans. These include Rocky Mountain spotted fever and Mediterranean spotted fever in humans and Ehrlichiosis, Babesiosis and Anaplasmosis in dogs [4]. Moreover, in the era of globalization and climate changes, the brown dog tick has becoming increasingly relevant from a public health perspective. This tick has also been implicated in the transmission of pathogens of zoonotic concern (e.g., Ricktettisa rickettsii) and recent studies have shown that $R$. sanguineus ticks exposed to high temperatures are more prone to bite humans [5].

Within the last few decades, newly identified tick-borne diseases or re-emergence of known tick borne diseases with new geographical patterns or prevalence have been described around the world. The important spreading pathogens by a greater mobility of human populations and their companion animals combined with changes in the ecosystems favorable to survival of ectoparasites have led to the recognition of tick borne diseases in areas usually considered as free of this infection [6]. $R$. sanguineus is a good example of parasite globalization to its ubiquitous distribution which has clearly been facilitated by dog movements with their owners or trough trade. As more attention is given to the care of the companion animals, especially in developed countries [7], and better detection tools (based on mollecular technique) allowing more sensitive and specific detection of tick-borne pathogens [8].

Tick- borne diseases are recognized as an emerging infectious threat not only to dogs but also to human. This information is still limited in Indonesia, whereas the epidemiological studies which support the emergence or re-emergence of tick-borne pathogen in dogs around the world is necessary. The present study will focus on the recent of ticks infestation and tick-borne diseases on the dog in several Cities of Indonesia based on direct observations, and medical record of Veterinary Clinics.

\section{Materials and Methods}

Location and time research: The ticks were collected in the Animal Police Directorate Security Agency (Baharkam) Kelapa Dua, Depok City and the Atang Sendjaja Air Force (ATS), Bogor City, and 21 Veterinary Clinics in Bogor, Jakarta and Bandung Cities. Tick identification and Ehrlichia rapid test analysis were carried out at the Laboratory of Entomology, while the identification of blood smear samples in Protozoology Laboratory, Department of Parasitology and Medical Entomology, Faculty of Veterinary Medicine, Bogor Agricultural University Indonesia. The research was conducted from March to December 2013. 


\section{Methodology}

Observations of tick infestations in dogs: Observations were done by counting the number of ticks in the fifth region of the body of a dog, i.e., (a) The head to neck including the ears, (b) the back, (c) the abdomen, (d) the legs and (e) the tail, then determination the degree of tick infestation. The processing tick specimens and the degree of tick infestations were based on Hadi and Rusli, as follows: $(-)=$ no ticks, $(+)=1-5$ ticks $($ mild), $(++)=6-10$ ticks (moderate), $(+++)=11-20$ ticks (high) and $(++++)=>20$ ticks (very high).

Observations tick infestations in the environment: Larval tick densities were estimated using the blanket dragging method. The tools used in the form of white fabric measuring $40 \mathrm{x} 40 \mathrm{~cm}$ surface is rough so the ticks will be easier to stick to the fabric. The fabric is then pulled over the field grass along the 5 to $10 \mathrm{~m}$ for 30 seconds [9]. Observations and sampling ticks also performed at the kennels manually.

Specimen processing and tick identification: The process of making preparations slide carried by ticks and Partosoejono and Ashadi method [10]. Identification of ticks using identification keys of Walker et al. [9].

Detecting ehrlichiosis, anaplasmosis and babesiosis: Blood and serum samples were obtained from $30 \%$ of examined dogs in Baharkam and ATS. Procedures of separation and storage of serum were based on Tsachev et al. [11]. The blood was collected by using a syringe and collected in vacutainer, then placed at room temperature until the process of coagulation. Vacutainer then centrifuged at $1700 \mathrm{~g}$ for 10 minutes to separate the serum. The serum was transferred into a microtube, then stored in a freezer temperature of $-20^{\circ} \mathrm{C}$. Dog serum samples examined using rapid test kits WITNESS Ehrlichia ${ }^{\circ}$ (Synbiotics) for the detection of antibodies against $E$. canis. Identification of Babesia and Anaplasma based on the blood staining method in accordance with Tampubolon [12].

Cases of tick infestations in dogs: Secondary data was taken from the dog patient's medical record at the 21 Veterinary Clinics in Bogor, Jakarta and Bandung. Data were collected from 2008 to 2013 and grouped by the breed of dog, age and sex. Data on 2013 were obtained from tick sample collection of patients in veterinary clinics conducted by the veterinarian in charge of each clinic. Dog tick samples from patients were put into the collection tubes containing $70 \%$ alcohol, and then identified in the Entomology Laboratory.

\section{Results and Discussion}

\section{Tick identification}

Out of 950 samples of ticks obtained from 97 dogs in Animal Police Directorate Security Agency (Baharkam) Depok, Atang Sendjaja Air Force Bogor, and 21 Veterinary Clinics in Bogor, Jakarta and Bandung, showed that only one species of tick found, i.e., Rhipicephalus sanguineus. This tick was elongated body shaped, reddish brown in color, and lacking any ornamentation. The size of the adult ticks \pm 1 $\mathrm{cm}$, and with the curve of anal (anal groove) in the posterior anus. $R$. sanguineus has a slightly convex-shaped eyes located on the lateral scutum, hexagonal basis capituli, short hypostome, festoons in the posterior part of the body, and spiracles shaped like a comma. The ventral part of the male tick with narrowed adanal shaped pieces, and the size of the pieces of additional adanal quite large. The female tick does not have the shield and additional Adanal. Dorsal basis capituli female ticks are a pair of porous area that secrete substances when ticks lay eggs. These substances serve to protect the eggs (waterproofing).

In Indonesia, Hadi and Rusli [13] reported from 28 ticks infested dogs in 6 districts of Bogor were identified as $R$. sanguineus. A similar result was reported in the Philippines, species of ticks that attacks the dog was $R$. sanguineus [14]. Dog ticks survey in four cities in India (Mumbai, Delhi, Sikkim and Ladakh) showed there were two genus of ticks i.e., Rhipicephalus and Haemaphysalis [15]. In Jeju island of South Korean, the ticks survey by using tick-drag showed $R$. sanguineus was never found, but Haemaphysalis longicornis, H. flava, H. phasiana, Ixodes nipponensis, I. turdus and Amblyomma testudinarium were collected well [16].

\section{Tick infestations in animal police directorate security agency (Baharkam)}

Baharkam is Security Maintenance Agency in charge of developing and conducting security management function that includes maintenance and improving the conditions of security and public order in order to realize security in the country (Indonesia). Here there are trained dogs and horses were assigned to assist the police to deal with various security problems. Tick infestation studies were carried out in the entire dog i.e., 81 dogs (53 males and 28 females). The prevalence of the tick infested dog was $67.90 \%$ ( 55 dogs). In Baharkam there were nine bred of dogs, i.e., Beagle, Doberman, Dutch Shepherd, German Pointer, German Shepherd, Golden Retriever, Labrador, Malinois and Rottweilers. Golden Retriever was the only breed of dog that was not infested with ticks compared to eight other breeds. Doberman and German shepherd were the highest tick infested dogs (100\%), followed by German Pointer (75\%), Malinois (70.83\%), Dutch Shepherd (70\%), Rottweiler (66.67\%), Labrador (56\%), and Beagle (50\%) (Table 1). In Baharkam, it was known that the Golden Retriever was rarely active in the field so the opportunities for contact with $R$. sanguineus outdoors was limited, and the tick transmission becomes small. Based on Pearson Chi-Square test, there was no relationship between the breed of dog with a degree of infestation of ticks ( $p>0.05)$. The similar results were reported in the Ashton Court Estate-UK, that factor of dog races/breeds did not affect the dog tick infestations [17].

\begin{tabular}{|l|l|l|l|l|}
\hline \multirow{2}{*}{ No } & Dog breeds & Number of dog & \multicolumn{2}{|l|}{ Number of tick infested dog } \\
\cline { 3 - 5 } & & & Total & $\%$ \\
\hline 1 & Beagle & 2 & 1 & 50 \\
\hline 2 & Doberman & 2 & 2 & 100 \\
\hline 3 & Dutch Shepherd & 10 & 7 & 70 \\
\hline 4 & German Pointer & 8 & 6 & 75 \\
\hline 5 & German Shepherd & 6 & 6 & 100 \\
\hline 6 & Golden Retriver & 1 & 0 & 0 \\
\hline 7 & Labrador & 25 & 14 & 56 \\
\hline 8 & Malinois & 24 & 17 & 70.83 \\
\hline 9 & Rottweiler & 3 & 2 & 66.67 \\
\hline & Total & 81 & 55 & 67.90 \\
\hline
\end{tabular}

Table 1: Prevalence of dogs infested by Rhipicepalus sanguineus at Baharkam based on dog breds. 
Page 3 of 7

Generally in Baharkam, those dogs were infested by mild tick infestation category (41.98\%), meanwhile in moderate category was $18.52 \%$, and in high and very high were $2.47 \%$ and $4.94 \%$ respectively. The percentage of male dogs were infested by ticks higher (45.68\%) than female dogs $(22.22 \%)$, but based on Pearson Chi-Square, there was no relationship between the sexes dog and degree of infestation of ticks ( $>0.05$ ) (Table 2). This was because the training activity or guard duty did not distinguish between male and female dogs, so both dogs have the same time spent outdoors and opportunity to be infested by ticks. Research in Algeria and Mexico also showed a similar result with this result $[18,19]$.

\begin{tabular}{|c|c|c|c|c|c|c|c|}
\hline \multirow[t]{2}{*}{ No } & \multirow[t]{2}{*}{ Degree of tick infestation catagory } & \multicolumn{3}{|c|}{$\begin{array}{l}\text { Baharkam dogs (\%) } \\
\text { Total }\end{array}$} & \multicolumn{3}{|c|}{ ATS dogs (\%) } \\
\hline & & Male & Female & Total & Male & Female & Total \\
\hline 1 & None (0 tick) & 19.75 & 12.35 & 32.10 & 0.00 & 0.00 & 0.00 \\
\hline 2 & mild (1-5 ticks) & 27.16 & 14.81 & 41.98 & 0.00 & 0.00 & 0.00 \\
\hline 3 & moderate (6-10 ticks) & 14.81 & 3.70 & 18.52 & 14.29 & 0.00 & 14.29 \\
\hline 4 & high (11-20 ticks) & 1.23 & 1.23 & 2.47 & 21.43 & 0.00 & 21.43 \\
\hline \multirow[t]{2}{*}{5} & very high (>20 ticks) & 2.47 & 2.47 & 4.94 & 35.71 & 28.57 & 64.29 \\
\hline & Total & 65.43 & 34.57 & 100 & 71.43 & 28.57 & 100 \\
\hline
\end{tabular}

Table 2: The degree of infestation of Rhipicepalus sanguineus in Baharkam and ATS dogs based on sex.

Based on information from veterinarians and the handler in Baharkam, not all the dogs were quite regularly bathed, however in some dogs were done. The statement indicated that the dogs without regularly bathed can be a source of tick infestations. The predilection sites of tick in the infested dogs at Baharkam varied. However the more preferred were in back regio 19 (35.0\%), head, ears and neck 16 (29.0\%), legs and interdigital spaces 8 (14.5\%), abdomen $6(10.9 \%)$ and tail $6(10.9 \%)$ in total of 55 infested dogs (Table 3$)$. The degree of infestation in the region of the back of the dog shows very high infestation. Ticks were found mainly in this area due to difficult for the dog to use his legs to get rid of a tick [20]. The behavior of an infested dog showed frequently scratching the body, especially the abdomen and head, ears, and neck in field training or in a kennel. This was because the effects of tick infestations caused such irritation. The tick larvae (Figure 1) were also found in Baharkam grass field which often use for the training of police dogs (about 71 larvae $/ 100 \mathrm{~m}^{2}$ area of the field). Grassy field for dog training was suspected for source infestation, because the infested dogs and the uninfested, practicing in the same field. When the infested training dogs entered their kennel, the transmission also move to the kennel area. This area will be suitable for the larvae and nymph for drop-offs and moulting. Drop-off also occurred in female tick to lay eggs and hide. Adult females will lay eggs in hidden places such as cracks and crevices walls, rocks and soil to protect themselves and their offspring from predators such as spiders, birds [21] and wasps [22]. $R$. sanguineus is an endophilic (adapted to indoor living), monotropic (all developmental stages feed on the same host species), and three-host (each life stage requires a new host to feed on) tick species. However, this tick is also able to survive in outdoor environments, and being able to adopt different strategies for survival [1].

\begin{tabular}{|c|c|c|c|c|c|c|}
\hline \multirow[t]{2}{*}{ Dog breed } & \multirow[t]{2}{*}{ No infested dog } & \multicolumn{5}{|c|}{ No of dog and the degree of tick infestation by predilection sites } \\
\hline & & $\begin{array}{l}\text { Head to neck } \\
\text { region }\end{array}$ & Back region & Abdomen region & Legs and interdigitals & Tail region \\
\hline Beagle & 1 & $1(++)$ & $1(++++)$ & $1(+)$ & $1(+)$ & $(-)$ \\
\hline Doberman & 2 & $(-)$ & $2(++) \sim(++++)$ & $(-)$ & $(-)$ & $(-)$ \\
\hline Dutch Shepherd & 7 & $3(-) \sim(+)$ & $2(-) \sim(+++)$ & $1(-) \sim(+)$ & $1(-) \sim(+)$ & $1(-) \sim(+)$ \\
\hline German Pointer & 6 & $3(-) \sim(+)$ & $3(+) \sim(++)$ & $1(-) \sim(+)$ & $1(-) \sim(+)$ & $1(-) \sim(+)$ \\
\hline German Shepherd & 6 & $2(-) \sim(+)$ & $2(-) \sim(+)$ & $1(-) \sim(+)$ & $1(-) \sim(+)$ & $1(-) \sim(+)$ \\
\hline Labrador & 14 & $5(-) \sim(++)$ & $5(-) \sim(++++)$ & $1(-) \sim(+)$ & $1(-) \sim(+)$ & $1(-) \sim(+)$ \\
\hline Malinois & 17 & $3(-) \sim(+)$ & $2(-) \sim(++)$ & $1(-) \sim(+)$ & $1(-) \sim(+)$ & $1(-) \sim(+)$ \\
\hline Rottweiller & 2 & $(-)$ & $2(+) \sim(++)$ & $(-)$ & $2(+) \sim(+++)$ & $1(-) \sim(+)$ \\
\hline
\end{tabular}


Citation: Hadi UK, Soviana S, Pratomo IRC (2016) Prevalence of Ticks and Tick-Borne Diseases in Indonesian Dogs. J Veterinar Sci Techno 7:

Page 4 of 7

\begin{tabular}{|l|l|l|l|l|l|l|}
\hline Total & 55 & $16(29.0 \%)$ & $19(35.0 \%)$ & $6(10.9 \%)$ & $8(14.5 \%)$ & $6(10.9 \%)$ \\
\hline
\end{tabular}

Table 3: The degree of infestation of Rhipicepalus sanguineus in Baharkam dogs based on predilection sites. $(-)=$ No tick ; $(+)=$ mild ; $(+$ $+)=$ moderate $;(+++)=$ high $;(++++)=$ very high infestation.

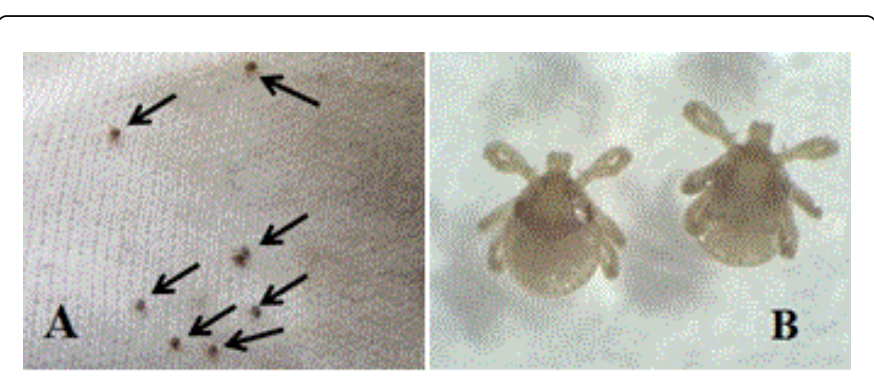

Figure 1: A) R. sanguineus larvae collected by tick-drag; B) Tick larvae in slide preparation.

\section{Tick infestations in Atang Sendjaja Air Force Bogor (ATS)}

Senjaya Atang Air Force Bogor is a military air base where security is also equipped with guard dogs whose number 14 of the race Golden Retriever and Rottweiler. The prevalence of tick infestation in ATS dogs were $100 \%$ in total of 14 dogs (10 males and 4 females). In general, tick infestation were belong to category of very high infestation (64.29\%), high (21.43\%) and moderate (14.29\%) (Table 2). Ticks predilection were found mostly on the dog's head to neck including ears (42.9\%) (Table 4). The tick larva was not found in ATS grass field, but positively inside the kennels.

\begin{tabular}{|l|l|l|l|l|l|l|}
\hline \multirow{2}{*}{ Dog breed } & No infested dog & \multicolumn{4}{l|}{ No of dog and the degree of tick infestation by predilection sites } \\
\cline { 3 - 7 } & & Head to neck region & Back region & Abdomen region & Legs and interdigitals & Tail region \\
\hline Golden Retriever & 2 & $1(+++)$ & $2(+) \sim(++)$ & $1(+)$ & $1(+)$ & $1(+)$ \\
\hline Rottweiller & 12 & $5(+) \sim(++++)$ & $2(+) \sim(++++)$ & $(-)$ & $1(+)$ & $(-)$ \\
\hline Total & 14 & $6(42.9 \%)$ & $4(28.6 \%)$ & $1(7.1)$ & $2(14.3)$ & $1(7.1)$ \\
\hline
\end{tabular}

Table 4: The degree of infestation of Rhipicepalus sanguineus in ATS dogs based on predilection sites.

\section{Tick infestation in veterinary clinic}

The cases of ticks infestation of dogs at Bogor, Jakarta and Bandung Veterinary Clinics ( 21 clinics in total) in 2008 to 2013 as many as 731 cases. In general, there was an increase of the ticks infestation prevalence at three cities in that range of year (Figure 2). This might illustrate the increasing of the awareness of the owner to check the dog to a veterinary clinic or because of the effect of climate change. In the years 2008-2011 and from January to June 2013, the average prevalence of tick infestations in Bogor higher than Jakarta and Bandung City.

The prevalence of tick infested dog based on bred, sex, and age in Bogor, Jakarta dan Bandung from 2008 to 2013 was presented in Table 5. Based on the dog breds, the purebred in three city showed the highest infestations (71.47\%) followed by crossbred (18.98\%) and local $\operatorname{dog}(9.55 \%)$. By sex, male dogs were more infested ticks (61.08\%) than the female (38.81\%). These data based on the patience coming to the veterinary clinic, so these results might be different in other countries.

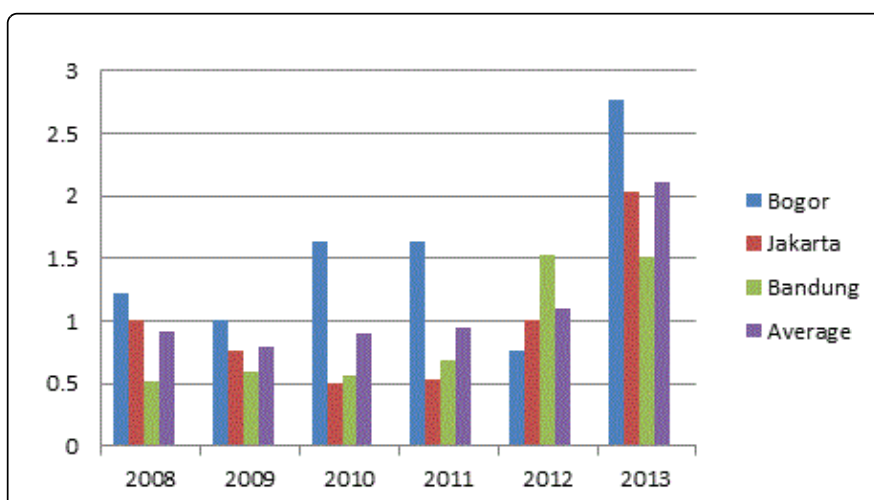

Figure 2: Prevalence of dog infested by tick in Bogor, Jakarta dan Bandung 2008-2013.

\begin{tabular}{|l|l|l|l|l|l|l|l|l|}
\hline \multirow{2}{*}{ City area } & \multicolumn{4}{|l}{ Dog bred (\%) } & \multicolumn{3}{l|}{ Sex (\%) } & \multicolumn{3}{l|}{ Age (\%) } \\
\cline { 2 - 10 } & Pure breed & Crossbreed & Local & Male & Female & $<1$ Year & $\mathbf{1 - 5}$ year & $>\mathbf{5}$ year \\
\hline Bogor & 84.91 & 6.92 & 8.18 & 60.13 & 39.87 & 53.33 & 34.29 & 12.38 \\
\hline Jakarta & 70.00 & 16.97 & 13.03 & 60.43 & 39.57 & 21.29 & 62.74 & 15.97 \\
\hline
\end{tabular}


Page 5 of 7

\begin{tabular}{|l|l|l|l|l|l|l|l|l|}
\hline Bandung & 59.50 & 33.06 & 7.44 & 62.69 & 37.31 & 54.72 & 37.74 & 7.55 \\
\hline Average & 71.47 & 18.98 & 9.55 & 61.08 & 38.91 & 43.11 & 44.92 & 11.96 \\
\hline
\end{tabular}

Table 5: Prevalence of dog infested by tick based on bred, sex, and age in Bogor, Jakarta dan Bandung tahun 2008-2013.

In Indonesia, the most owners of purebred dogs belong to higher income persons, and they more aware to bring their dogs for the health checked. In addition, the most dog owner only has the male dog, and the most patience coming to the veterinary clinic in three cities were the male. Papazahariadou et al. [23] reported that the dog tick infestation varies between races or breds in Thessaloniki, northern Greece. He also noted that the purebred dogs group more infested by ticks (41.78\%), while the crossbred was $18.9 \%$ and mongrel was $39.4 \%$.

The prevalence of tick infested dogs based on three age groups as derscribe by Hadi and Rusli [2] and VCA [24] showed that the young dog (under 1 year old) and adult (between 1 and 5 years old) were more infested $(43.11 \%$ and $44.92 \%$ respectively) than the older one (over 5 years old) with lower prevalence $(11.96 \%)$. However, the significant prevalence of infested dogs aged 1-5 years old (62.74\%) was shown at the veterinary clinics in Jakarta, and the prevalence of infested dog in Bogor and Bandung almost similar.

\section{Ehrlichiosis, babesiosis and anaplasmosis detection}

The detection results of Baharkam dog sera samples showed 12\% positively E. canis, and $40 \%$ from ATS Samples. The positive result in Baharkam was originally come from the dogs with moderate tick infestation category (40\%) and without ticks (12.5\%). While ATS dog sera that $E$. canis positive were come from dogs with moderate and high degree of tick infestation. Based on Chi-Square test, there was no relationship between degree of ticks infestation to $E$. canis infection $(\mathrm{P}>0.05)$. In addition, the dogs with $E$. canis positive both from
Baharkam and ATS showed no clinical symptoms and happened in ages ranging from 1 to 3 years olds. These subclinical stages of Ehrlichiosis were also reported in several countries in the world. Cardoso et al. [25] in Portugal reported that $4.1 \%$ of 557 healthy dogs found to have antibodies to E. canis. These antibodies can be persisted for a long time in the dog's body, and can be seen in subclinical infection [26]. However, as dogs in Baharkam and ATS, the incidence of Ehrlichiosis in dogs in Brazil did not show the clinical symptoms [27-29].

The result of blood smear examination of Baharkam dogs showed positively Babesia sp (8\%) and Anaplasma sp (16\%), while samples of ATS were all negative (Table 6). Babesia sp infection in Baharkam dogs originated from the dog with moderate and high tick infestations. However, the analysis Pearson Chi-Square test explained that the degree of infestation of tick was not associated with Babesia sp and Anaplasma sp infections ( $\mathrm{p}>0.05)$. Babesia sp density percentage was $0.4 \%$ in the dog with moderate tick infestations and $0.2 \%$ in the high category (Table 7). Mixed infections between E. canis and blood Protozoa such as Babesia sp and Theleria were reported in dogs of South Africa [30]. Although dogs are the main hosts of $R$. sanguineus, the finding of this tick on wild canids [31] indicates that free-ranging wild canids might be involved in its maintenance and dispersion through different regions. This could have implications in the control of ticks and in the epidemiology of tick-borne diseases, particularly in areas where dogs live in close contact with their wild counterparts.

\begin{tabular}{|c|c|c|c|c|c|c|c|c|}
\hline \multirow[t]{2}{*}{ Dogs category } & \multicolumn{2}{|c|}{ No dog examined } & \multicolumn{2}{|c|}{ Ehrlichia canis (\%) } & \multicolumn{2}{|c|}{ Babesia sp (\%) } & \multicolumn{2}{|c|}{ Anaplasma sp (\%) } \\
\hline & Baharkam & ATS & Baharkam & ATS & Baharkam & ATS & Baharkam & ATS \\
\hline None (0 tick) & 8 & 0 & $1(12.5)$ & 0 & 0 & 0 & $2(25)$ & 0 \\
\hline mild (1-5 ticks) & 10 & 0 & 0 & 0 & 0 & 0 & 0 & 0 \\
\hline $\begin{array}{l}\text { moderate } \quad(6-10 \\
\text { ticks) }\end{array}$ & 5 & 1 & $2(40)$ & $1(100)$ & $1(20)$ & 0 & $1(20)$ & 0 \\
\hline high (11-20 ticks) & 1 & 1 & 0 & $1(100)$ & $1(100)$ & 0 & 0 & 0 \\
\hline $\begin{array}{l}\text { very } \text { high } \quad(>20 \\
\text { ticks) }\end{array}$ & 1 & 3 & 0 & 0 & 0 & 0 & $1(100)$ & 0 \\
\hline Total & 25 & 5 & $3(12)$ & $2(40)$ & $2(8)$ & 0 & $4(16)$ & 0 \\
\hline
\end{tabular}

Table 6: Detection result of E. canis, Babesia sp, and Anaplasma sp infections among dogs of Baharkam and ATS in September 2013.

\begin{tabular}{|l|l|}
\hline Dogs catagory & Density of Babesia sp (\%) \\
\hline None $(0$ tick) & 0 \\
\hline Moderate $(6-10$ ticks) & 0.4 \\
\hline High (11-20 ticks) & 0.2 \\
\hline
\end{tabular}

\begin{tabular}{|l|l}
\hline Very high $(>20$ ticks) & 0
\end{tabular}

Table 7: Density of Babesia sp infected dogs of Baharkam in September 2013. 


\section{Conclusion}

The tick infested dog in Depok, Bogor, Jakarta and Bandung based on the morphological characters was only one species i.e., Rhipicephalus sanguineus. The prevalence of dogs infested by ticks in Baharkam was $67.90 \%, 100 \%$ in ATS, and the prevalence in 21 Veterinary Clinic in Jakarta, Bogor, and Bandung 2008-2013 tend to be increased every year. The predilection $R$. sanguineus in Baharkam dogs were more in the region of the back (35\%) and head, the ears and the dog's neck (29\%), but also on the legs and interdigital spaces (14.5\%), abdomen (10.9\%) and tail (10.9\%). The tick larvae were found not only in the kennel (indoor) in grass field (outdoor environment) especially in Baharkam which often use for the training of police dogs. These places can be a source of transmission of tick infestation among dogs. Based on the dog breds, the purebred in three city showed the highest infestations (71.47\%) followed by crossbred (18.98\%) and local dog (9.55\%). By sex, male dogs were more infested ticks (61.08\%) than the female $(38.81 \%)$. The prevalence of tick infested dogs based on three age groups showed that the young dog (under 1 year old) and adult (between 1 and 5 years old) were more infested (43.11\% and $44.92 \%$, respectively) than the older one (over 5 years old) with lower prevalence (11.96\%). The prevalence of Ehrlichiosis on Baharkam dog was $12 \%$, and $40 \%$ on ATS dogs. Positive result in Baharkam were originally come from the dogs with moderate tick infestation category $(40 \%)$ and without ticks (12.5\%). The positive result in Baharkam were originally come from the dogs with moderate tick infestation category (40\%) and without ticks (12.5\%). The results of blood smear examination on Baharkam dogs showed positive Babesia (8\%) and Anaplasma (16\%). There were no correlation between the degree of infestation of ticks with infection of E. canis, Babesia and Anaplasma $(\mathrm{p}>0.05)$.

\section{Acknowledgements}

We would like to express my thanks to Dr Chaindra Prasto Saleh and Dr Adi Purnomo from Animal Police Directorate Security Agency (Baharkam) Depok, and Dr. Mawar Subangkit from Senjaya Atang Air Force (ATS) Bogor, who permitted us for doing tick collections and detecting their dogs for Ehrlichiosis, Babesiosis and Anaplosmosis diagnosis. Thanks also to all staffs in Entomology Laboratory, Division of Parasitology and Medical Entomology, Faculty of Veterinary Medicine, Bogor Agricultural University for their assistance in taking tick collections, preservations, identifications, and data analyzing for publication.

\section{References}

1. Dantas-Torres F (2010) Biology and ecology of the brown dog tick, Rhipicephalus sanguineus. Parasit Vectors 3: 26.

2. Hadi UK, Rusli VL (2006) Infestasi Caplak Anjing Rhipicephalus sanguineus (Parasitiformes: Ixodidae) di Daerah Kota Bogor. J Med Vet Indones 10: 55-60.

3. Uspensky I, Ioffe-Uspensky I (2002) The dog factor in brown dog tick Rhipicephalus sanguineus (Acari: Ixodidae) infestations in and near human dwellings. Int J Med Microbiol 291 Suppl 33: 156-163.

4. Otranto D, Dantas-Torres F, Breitschwerdt EB (2009) Managing canine vector-borne diseases of zoonotic concern: part one. Trends Parasitol 25: 157-163.

5. Parola P, Socolovschi C, Jeanjean L, Bitam I, Fournier PE, et al. (2008) Warmer weather linked to tick attack and emergence of severe rickettsioses. PLoS Negl Trop Dis 2: e338.
6. Beugnet F, Marié JL (2009) Emerging arthropod-borne diseases of companion animals in Europe. Vet Parasitol 163: 298-305.

7. Berrada ZL, Telford SR 3rd (2009) Burden of tick-borne infections on American companion animals. Top Companion Anim Med 24: 175-181.

8. Shaw SE, Day MJ, Birtles RJ, Breitschwerdt EB (2001) Tick-borne infectious diseases of dogs. Trends Parasitol 17: 74-80.

9. Walker AR, Bouattour A, Camicas JL, Estrada-Peña A, Horak IG (2013) Ticks of Domestic Animals in Africa: a Guide to Identification of Species. UK (GB): Bioscience Reports. Edinburgh Scotland, p: 26.

10. Partosoejono S, Ashadi G (1992) Penuntun Laboratorium Parasitologi I Departemen Pendidikan dan Kebudayaan Dirjen Pendidikan Tinggi Pusat Antar Universitas Bioteknologi IPB.

11. Tsachev I, Kontos V, Zarkov S, Krastev S (2006) Survey of antibodies reactive with Ehrlichia canis among dogsin South Bulgaria. Rev Med Vet 157: 481-485.

12. Tampubolon M (1992) Petunjuk Laboratorium Protozoologi. Bogor (ID), IPB Press.

13. Hadi UK, Soviana S (2010) Ektoparasit: Pengenalan, Identifikasi dan Pengendaliannya. Bogor (ID): IPB Press.

14. Baticados AM, Baticados WN (2011) Serological Evidence for Ehrlichia canis Exposure in Military Dogs and Other Canines in Metropolitan Manila, Philippines. J Vet Med 66: 151-156.

15. Abd Rani PA, Irwin PJ, Coleman GT, Gatne M, Traub RJ (2011) A survey of canine tick-borne diseases in India. Parasit Vectors 4: 141.

16. Ko S, Kang JG, Kim SY, Kim HC, Klein TA, et al. (2010) Prevalence of tick-borne encephalitis virus in ticks from southern Korea. J Vet Sci 11: 197-203.

17. Jennett AL, Smith FD, Wall R (2013) Tick infestation risk for dogs in a peri-urban park. Parasit Vectors 6: 358

18. Vazquez CC, Vazquez ZG, Soto YMM (1998) Prevalence of Rhipicephalus sanguineus Infestation in Dogs in Cuernavaca, Morelos, Mexico. Parasitol día 22: 1-2.

19. Matallah F, Benakhla A, Medjouel L, Matallah S (2012) Tick Infestation of Dogs and Prevalence of Canine Babesiosis in The North-East of Algeria: Area of El-Tarf. Am-Eurasian J Sustain Agric 6: 126-134.

20. Gracia LT, Romero HQ, Martínez MTQ, Evangelista TBR, Medina YG, et al. (2009) Prevalence of Ticks (Rhipicephalus sanguineus) in Dogs from an Urban Mexico-US Border Region: A Pilot Study.

21. Guglielmone AA, Mosa SG (1991) Predation of Ticks of the Rhipicephalus sanguineus (Latreille, 1806) Group and Boophilus microplus (Canestrini, 1888) (Acari: Ixodidae) by Nothura temminck, 1815 (Aves: Tinamidae) in Salta, Argentina. Folia Parasitol. 38: 114. Di dalam: Dantas-Torres F. 2010. Biology and Ecology of The Brown Dog Tick, Rhipicephalus sanguineus. Par \& Vect 3: 1-11.

22. Coronado A (2006) Ixodiphagus hookeri Howard, 1907 (Hymenoptera: Encyrtidae) in The Brown Dog Tick Rhipicephalus sanguineus Latreille, 1806 (Acari: Ixodidae) in Venezuela. Entomotropica 21: 61-64.

23. Papazahariadou MG, Saridomichelakis MN, Koutinas AF, Papadopoulos EG, Leontides L (2003) Tick infestation of dogs in Thessaloniki, northern Greece. Med Vet Entomol 17: 110-113.

24. VCA (2014) Veterinary Centers of America Animal Hospitals. Dog Life Stages.

25. Cardoso L, Mendão C, Madeira de Carvalho L (2012) Prevalence of Dirofilaria immitis, Ehrlichia canis, Borrelia burgdorferi sensu lato, Anaplasma spp. and Leishmania infantum in Apparently Healthy and CVBD-suspect Dogs in Portugal - A National Serological Study. Par \& Vect 5: 1-9.

26. Tornquist SJ (2012) The Merck Veterinary Manual for Veterinary Professionals. Diagnostic Procedures for the Private Practice Laboratory Merck Sharp \& Dohme Corp. Merck \& Co Inc., Whitehouse Station, USA.

27. Nakaghi ACH, Machado RZ, Costa MT, André MR, Baldani CD (2008) Canine Ehrlichiosis: Clinical, Hematological, Serological and Molecular Aspects. Ciência Rural 38: 766-770. 
Citation: Hadi UK, Soviana S, Pratomo IRC (2016) Prevalence of Ticks and Tick-Borne Diseases in Indonesian Dogs. J Veterinar Sci Techno 7: 330. doi:10.4172/2157-7579.1000330

Page 7 of 7

28. Rahman WA, Ning CH, Chandrawathani P (2010) Prevalence of canine ehrlichiosis in Perak State, peninsular Malaysia. Trop Biomed 27: 13-18.

29. Oriá AP, Neto FAD, Machado RZ, Santana ÁE, Guerra JL, et al. (2008)

Ophthalmic, Hematologic and Serologic Findings in Dogs with Suspected Ehrlichia canis Infections. R Bras Ci Vet 15: 94-97.

30. Matjila PT, Leisewitz AL, Jongejan F, Penzhorn BL (2008) Molecular detection of tick-borne protozoal and ehrlichial infections in domestic dogs in South Africa. Vet Parasitol 155: 152-157.
31. Labruna MB, Jorge RS, Sana DA, Jácomo AT, Kashivakura CK, et al. (2005) Ticks (Acari: Ixodida) on wild carnivores in Brazil. Exp Appl Acarol 36: 149-163. 